\title{
Cellulose decomposed faster in fallow soil than in meadow soil due to a shorter lag time
}

\author{
Dominika Chmolowska $^{1}$ (D) Natnael Hamda $^{2} \cdot$ Ryszard Laskowski $^{3}$
}

Received: 21 June 2016 / Accepted: 21 August 2016 / Published online: 12 September 2016

(C) The Author(s) 2016. This article is published with open access at Springerlink.com

\begin{abstract}
Purpose The study aimed at comparing organic matter decomposition in two semi-natural agrobiocenozes, namely fallows and meadows, with similar plant biomass but differing in plant community composition and diversity and in succession stage.

Materials and methods The decomposition rate of a standard material (cellulose) was measured in soils from six fallows and six meadows spanning a few kilometres apart. The mathematical model was fitted to the data.

Results and discussion The model showed a significantly longer lag-time in cellulose decomposition in the meadows. Despite the delayed start of decomposition in the meadows, the estimated decomposition rates were similar in both ecosystem types, once the decay started.

Conclusions The faster start of decomposition in fallows seems to be promoted by higher contents of nitrates and phosphates in the fallow soils. The fallows, as younger ecosystems,
\end{abstract}

Responsible editor: Zucong Cai

Electronic supplementary material The online version of this article (doi:10.1007/s11368-016-1536-9) contains supplementary material, which is available to authorized users.

Dominika Chmolowska

dominika.chmolowska@o2.pl; chmolowska@isez.pan.krakow.pl

1 Institute of Systematics and Evolution of Animals, Polish Academy of Sciences, Sławkowska 17, 31-016 Krakow, Poland

2 College of Food, Agricultural and Natural Resource Sciences CFANS, University of Minnesota, 135 Skok Hall, 2003 Upper Buford Circle, St Paul, MN 5510, USA

3 Institute of Environmental Sciences, Jagiellonian University, Gronostajowa 7, 30-387 Krakow, Poland may have faster $\mathrm{C}$ turnover than older grasslands due to remains of fertilisers on these ex-arable fields.

Keywords Decay · Degradation · Grassland · Model · Succession · Utilisation

\section{Introduction}

Because as much as $95 \%$ of organic matter degradation in terrestrial ecosystems is performed by soil microorganisms (Berg and McClaugherty 2008), factors related to their activity affect organic matter decomposition. The most important abiotic factors are temperature, moisture, soil $\mathrm{pH}$ and the availability of nutrients. Organic matter decomposition is a multistep process, with a succession of microbes with different enzymatic capabilities. Most of the enzymes are extracellular and the production of many is induced by the presence of particular compounds. Cellulose is a stable compound with a half-life of 5-8 million years for $\beta$-glucosidic bond cleavage at $25{ }^{\circ} \mathrm{C}$ (Wolfenden and Snider 2001). The microbial enzymes speed up the process, and pure cellulose decays in soil within weeks or months. In the first stage of the cellulose decomposition, the polymer is broken down into disaccharide cellobiose in the presence of enzyme cellulase and then into glucose with the enzyme cellobiase. Cellulases are constitutive enzymes widely distributed across taxa, including fungi, bacteria, and protists (Bayer et al. 2006). When fresh substrate appears in the environment, its degradation starts with small amounts of cellulases already present in the soil. The hydrolysis products of this initial cellulose decomposition promote its further degradation by activating enzyme synthesis by microorganisms (Chen 2014). When the product concentration reaches the limit value, the hydrolysis is inhibited, but the 
succession of organisms consuming cellobiose allows for further cellulose degradation (Bayer et al. 2006).

While the factors driving decomposition directly, such as climate, plant litter structure and chemical composition, edaphic condition or contaminants, have been studied extensively, especially in forest ecosystems (e.g. Berg and McClaugherty 2008; Laskowski 2012), there is little evidence on how more complex ecosystem properties, like ecosystem type and age, can interact with decomposition in non-forest ecosystems. The grasslands differ from forests in a number of properties; for example, the decay of plant litter and $\mathrm{N}$ mineralisation can be limited by decomposing microbiota instead of plant litter quality (Chapman et al. 2006). The few available studies comparing decomposition in secondary succession of grasslands point at higher decay rates in young ecosystems. In the 0-, 5-, and 10year-old fallows after burning, the decomposition was slower in the older stands but was accompanied by faster nutrient loss from the litter (Toky and Ramakrishnan 1984). Also, Garnier et al. (2004) observed that in 2- to 42 year-old fields, the decomposition rate decreased during the secondary succession. The explanation of these two, otherwise similar, cases is, however, different: while the former was explained by the higher nutrient availability from the ash after vegetation burning, the latter was explained by differences in the functional traits of the plant species. Fast-growing species with high-quality litters are replaced during succession by slow-growing ones with lower quality litters. These two examples show that there is no one, simple explanation of how the succession is related to decomposition in real ecosystems, and that the decomposition can be modified by factors characteristic for each ecosystem.

This study was conducted with the aim of comparing the decomposition potential in the two ecosystem types differing in age, succession level, and stability, followed by plant community differences, while similar in plant biomass. Six fallow fields, which represent a young ecosystem under succession with low plant diversity characteristic for the early stages of secondary succession, were juxtaposed with six meadows representing an older ecosystem with higher plant diversity. The two ecosystem types were also chosen for practical purposes. Grasslands cover about $30 \%$ of the Earth's ice-free surface and are critical for supporting livestock and biodiversity (White et al. 2000). At the same time, European farmland has been abandoned at an unprecedented rate over the last few decades, resulting in an increase of the area of fallows (Keenleyside and Tucker 2010; Renwick et al. 2013) and a decrease in meadow biodiversity (Burel and Baudry 1995; Losvik 1999; Mitlacher et al. 2002; Tasser and Tappeiner 2002; Pavlů et al. 2005). Even more land is predicted to be deserted (Keenleyside and Tucker 2010). This has created a need to study on-going changes in different successional stages of such typical anthropogenic secondary succession.

Cellulose is the most abundant carbohydrate present in plant residues (Lynd et al. 2002). Crystalline cellulose (filter paper) is the main form of cellulose in most plant cell walls (Wilson 2011). Using standardised cellulose in studies on organic matter, decomposition allows to exclude effects of substrate variability and directly compare microbial activity under strictly controlled experimental conditions. Based on our laboratory experiment, we developed a function allowing for a lag time in decomposition and a non-zero decay asymptote because the data did not fit to the standard one-compartment exponential model proposed by Olson (1963).

\section{Materials and methods}

The soil for cellulose decomposition experiment was sampled in June 2010 from six fallows and six meadows located a few kilometres apart in southern Poland, Polish Western Outer Carpathians, $\left(49^{\circ} 25^{\prime} 17^{\prime \prime} \mathrm{N}, 20^{\circ} 57^{\prime} 33^{\prime \prime} \mathrm{E}\right)$. The type of grassland was determined according to the floristic composition and diversity. For fallows, the indicators were the presence of ruderal and segetal weeds, especially couch grass Elymus repens and low plant diversity-less than 27 species per $25 \mathrm{~m}^{2}$. The meadows had a higher richness, with 35-50 plant species per $25-\mathrm{m}^{2}$ plot, and a high proportion of species characteristic for the Molinio-Arrhenatheretea class and also of legumes (Chmolowska et al. 2016). The fallow soils had much higher contents of nitrates and available $\mathrm{P}$ and $\mathrm{K}$ than meadow soils and a slightly lower water-holding capacity and C: N ratio (Chmolowska et al. 2016). Apart from that, the soils did not differ between ecosystem types in total $\mathrm{C}, \mathrm{N}, \mathrm{Ca}$, $\mathrm{Na}, \mathrm{Mn}, \mathrm{NH}_{4}{ }^{+}$, organic matter $(\mathrm{OM})$, sand, silt, fine contents, and cation exchange capacity (CEC). The main soil characteristics and differences are presented in Table 1 . The soil microbial community activity, structure, and biomass were measured in 2009 in detail (Chmolowska et al. 2016).

Ten soil cores 10-cm deep were taken from each site along an 18-m transect. Cores from one plot were pooled and then sieved through a 4-mm mesh. Field-moist soils were stored at $4{ }^{\circ} \mathrm{C}$ until starting the experiment.

The decomposition rate was estimated according to Grunda (1967), based on a visual examination of the filter paper diminishment in laboratory conditions. Field-moist soil samples corresponding to about $25-35 \mathrm{~g}$ dwt. were placed in $94-\mathrm{mm}$ Petri dishes and six $10 \times 50$-mm strips of paper filter (389, Munktell) were laid on the soil surface. Visual readings against a template on plexiglass with a $5 \times 5-\mathrm{mm}$ grid were done once a week in the weeks $3-10$ of the incubation. Six subsamples (individual stripes) per soil sample were used rather than nine as in the original method, because of the soil shortage. The experiment was a part of a larger project consisting of a number of other tests and biological-chemical analyses. To compensate for the lower number of subsamples (filter paper strips) and decrease the measurement error, a visual examination was performed twice, independently by 


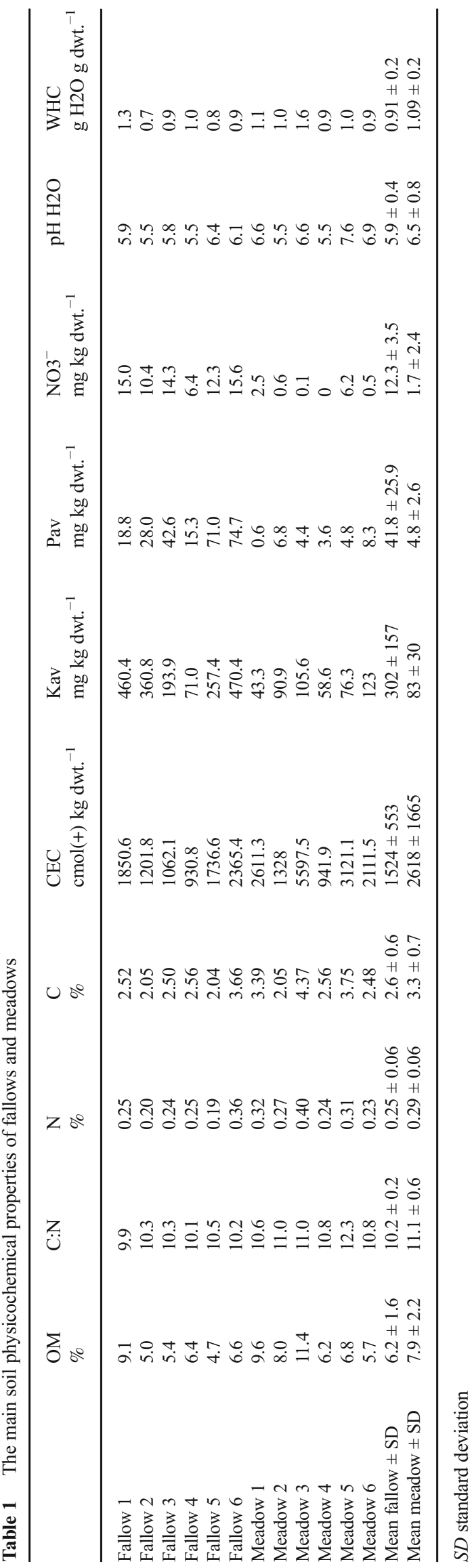

two people (two analytical replicates of six subsamples). The dishes were kept in darkness at room temperature, and the soil moisture was maintained by spraying the surface with deionised water twice a week.

Because apparent lag time was observed in some soils before decomposition started, instead of using the simple onecompartment Olson (1963) model, we used a more flexible equation, allowing for a lag-time and decomposition asymptote lower than $100 \%$ :

$\mathrm{ML}=\frac{1}{\left(\frac{1}{a}\right)+\mathrm{s} \cdot e^{-k \cdot t}}$

where $M L$ is the material loss ( $\%$ decomposed), $a$ is an asymptote (\% decomposed), $s$ is the shape of a curve and lag time, $t$ is time (weeks), and $k$ is decomposition rate constant in the exponential phase $\left(\right.$ week $\left.^{-1}\right)$.

Because in few soils, the decomposition did not reach the plateau during 10 weeks of incubation, the asymptotes would be estimated with high uncertainty. We assumed, thus, that $\alpha$ cellulose decays in soil at $100 \%$ and set the asymptote in the model to $100 \%$ in all cases. The function was fitted separately to data from each soil/plot. Model (Eq. (1)) parameters were estimated using the Marquardt method. To compare the two ecosystem types, a median test was used because the data did not pass the assumptions for parametric tests. Rank correlations were used to find out which soil chemical and biological properties correlate with the lag time $(s)$, decomposition rate $(k)$. In the matrix contents of $\mathrm{OM}, \mathrm{Ca}$, available $\mathrm{K}$ and $\mathrm{P}$, $\mathrm{NO}_{3}{ }^{-}, \mathrm{NH}_{4}{ }^{+}$together with $\mathrm{pH}\left[\mathrm{H}_{2} \mathrm{O}\right]$, and $\mathrm{CEC}$ were used in case of physicochemical soil properties. Follow soil basal respiration calculated per soil organic matter content and dry wieight, substrate induced respiration (SIR), metabolic quotient coefficient qCO2, soil enzymes activities (urease, acid and alkaline phosphatase), culturability, Biolog ECO plate parameters, and PLFA biomass (total PLFA and NLFA biomass, PLFA:NLFA, PLFA:C and MUFA:STFA ratios, relative contents of fungi, bacteria, Actinomycetales, protozoa, AMF and ratios of bacteria $\mathrm{G}(+): \mathrm{G}(-)$ and fungi:bacteria PLFA). All statistical tests were performed in Statgraphics Centurion XVI (Statpoint Technologies, Inc.).

\section{Results}

The cellulose decayed visibly faster in fallow than in meadow soils (Fig. 1), with $95 \%$ of material decomposed on average after 10 weeks in the fallow soils against $82 \%$ in meadows (Electronic Supplementary Material). According to the median test, the two groups differed significantly $(U=5.0$, $p=0.05$ ). Meadow 3, with only $40 \%$ of cellulose decomposed, differed substantially from the other plots. The 


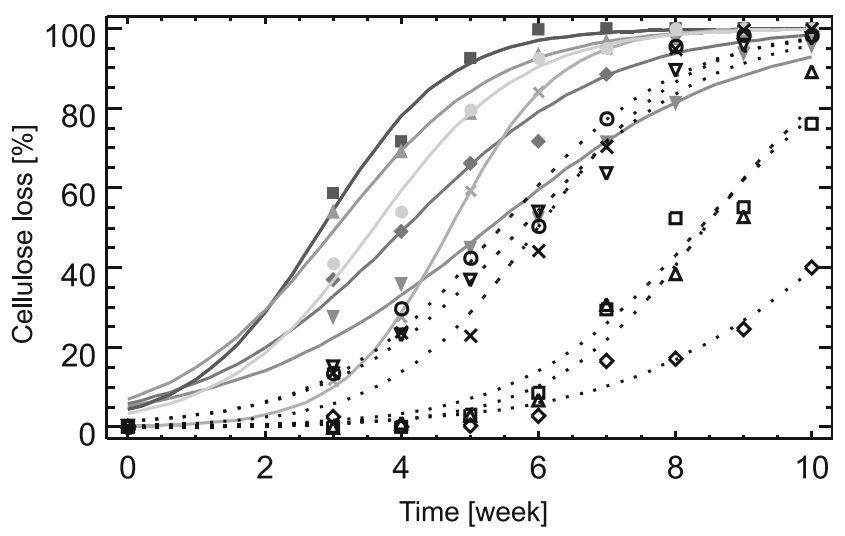

Fig. 1 Results of fitting the function $\mathrm{ML}=1 /((1 / \mathrm{a})+s$ exp. $(-k \cdot \mathrm{t}))$ to cellulose decomposition in the fallow and meadow soils. $a$ - asymptote (set to $100 \%$ in this work), $s$ - lag time, $k$ - decomposition rate in exponential phase. Solid lines and filled points indicate the fallows, broken lines and open points indicate the meadows. Point symbols indicate the plot number. Gray filled circle, fallow 1; gray filled diamond, fallow 2; gray filled inverted triangle, fallow 3; gray filled triangle, fallow 4; gray cross mark, fallow 5; gray filled circle, fallow 6; black empty square, meadow 1 , black empty inverted triangle, meadow 2; black empty diamond, meadow 3; black empty triangle, meadow 4; black empty circle, meadow 5; black cross mark, meadow 6

implemented model (Eq. (1)) fitted the cellulose decomposition data well, with $R^{2}$ between 96 and $99 \%$ (Table 2). The decomposition rate constant in the exponential phase $(k)$ was similar in both ecosystem types, while the lag time/shape parameter $(s)$ was significantly higher in the meadow soils $(U=33, p=0.02)$. Higher $s$ in the meadow soils means that cellulose decomposition in meadows was postponed in comparison to fallows, while the rate of decay-when starteddid not differ between the ecosystems. High $s$ values in meadows 1 and 3 are connected with the long lag-time and

Table 2 Results of fitting the function ML $=1 /((1 / \mathrm{a})+s \exp .(-k \cdot \mathrm{t}))$ to cellulose decomposition in fallow and meadow soils; $a$ - asymptote (set to $100 \%$ in this work), $s$ - lag time, $k$ - decomposition rate in exponential phase

\begin{tabular}{lrrlll}
\hline Plot & \multicolumn{1}{l}{$s$} & \multicolumn{1}{l}{$\mathrm{SE}$} & \multicolumn{1}{l}{$k$} & $\mathrm{SE}$ & $\mathrm{R}^{2}$ \\
\hline Fallow 1 & 0.22 & 0.11 & 1.08 & 0.14 & 99.02 \\
Fallow 2 & 0.16 & 0.05 & 0.68 & 0.07 & 98.52 \\
Fallow 3 & 0.18 & 0.05 & 0.55 & 0.05 & 98.17 \\
Fallow 4 & 0.13 & 0.05 & 0.85 & 0.10 & 98.76 \\
Fallow 5 & 4.15 & 0.62 & 1.28 & 0.03 & 99.96 \\
Fallow 6 & 0.28 & 0.10 & 0.93 & 0.08 & 99.30 \\
Meadow 1 & 5.94 & 5.12 & 0.76 & 0.10 & 96.96 \\
Meadow 2 & 0.65 & 0.25 & 0.73 & 0.07 & 98.80 \\
Meadow 3 & 5.07 & 3.47 & 0.58 & 0.07 & 95.80 \\
Meadow 4 & 17.78 & 23.53 & 0.89 & 0.16 & 96.20 \\
Meadow 5 & 0.72 & 0.39 & 0.78 & 0.09 & 98.14 \\
Meadow 6 & 2.64 & 2.38 & 0.93 & 0.15 & 97.38 \\
\hline
\end{tabular}

SE standard error low-curve concave. An extremely high $s$ value was observed in meadow 4 , which means 0 a particularly long lag-time, after which the curve concaved and the decomposition sped up by the end of incubation. When comparing the lag-time $(s)$, the decomposition rate $(k)$ needs to be taken into account simultaneously. Fallow 5 , to a smaller extent, was a similar case to meadow 4, within fallows (Fig. 1). Cellulose decomposition lag-time $(s)$ was negatively correlated with nitrate $(r=-0.64$, $p=0.03)$ and phosphate $(r=-0.63, p=0.04)$ contents in the soil. The $s$ was correlated to nitrogen mineralisation rate $(r=-0.61, \mathrm{p}=0.04)$.

\section{Discussion}

Our results confirm the presumption that organic matter decay is shaped by factors characteristic for each ecosystem. Significant difference between the two ecosystem types in decomposition pattern, despite the use of a uniform substrate, points to factors other than substrate quality determining the decay. The decomposition was most probably affected by past human management: remains of fertilisers in the ex-arable fields. In general, $\mathrm{C}$ is the most important resource for microbial growth, $\mathrm{N}$ is the secondary limiting nutrient, followed by P (e.g., Göransson et al. 2011). Because there are no significant differences between the studied fallows and meadows in total $\mathrm{C}$ quantity in the soils, we can neglect the effect of $\mathrm{C}$ differences between the two ecosystem types. The significant correlation between nitrate and phosphate concentration and decomposition lag-time (shape parameter $s$ ) indicates that, when $\mathrm{C}$ stock is similar, the available $\mathrm{N}$ and $\mathrm{P}$ play important roles in determining the conditions for efficient carbon use and microbial metabolism. Adding carbon substrate to soils changes the status of their microbial communities from $\mathrm{C}$ limited to limited by other nutrients. In an N-limited soil, the added easily available $\mathrm{C}$ was not immediately utilized (Kamble and Bååth 2014), which corroborates the lag in cellulose decomposition in the meadow soils. A meta-analysis on plant litter decomposition in tundra, forest and grassland ecosystems confirms that low ambient $\mathrm{N}$ fertilisation $\left(<5 \mathrm{~kg} \mathrm{ha}^{-1}\right.$ year $\left.^{-1}\right)$ and low lignin content of litter stimulate decomposition (Knorr et al. 2005). The relationship between ecosystem age, nutrients limitations and decomposition is not straightforward. In tropical forest soils the litter decomposition was enhanced by combined $\mathrm{N}$ and $\mathrm{P}$ fertilisation in old stands, which were P-limited. $\mathrm{N}$ supplementation alone did not increase the litter utilisation, even in young $\mathrm{N}$-limited forest (Hobbie and Vitousek 2000).

The findings of this study are in agreement with another cellulose decomposition experiment from the same plots performed a year earlier. In that study lower cellulose weight loss was measured in meadows at a single time-point, in 4 weeks of incubation in laboratory conditions. Lower $\mathrm{N}$ 
mineralization rate and nitrification potential were also found in the meadows (Chmolowska et al. 2016). The data may indicate, thus, higher carbon and nutrient turnover rates in fallows than in meadows, perhaps due to higher microbial substrate activity, regardless similar microbial biomass (Chmolowska et al. 2016). Riggs et al. (2015) studied the effect of $\mathrm{N}$ fertilisation on organic matter decomposition in fast pool and slow pool of SOM in five grasslands in Northern America. The results were site-depended. In two more sandy northern plots, $\mathrm{N}$ amendment increased fast pool decay and had no effect on slow pool decay in contrary to other plots. In more fertile southern plots, slow pool decay descended under $\mathrm{N}$. The site-effect differences can be perhaps linked to the initial balance of nutrients. Ratios of CNPS are crucial for SOM build up or decomposition (Kirkby et al. 2013, 2014). It is worthy to mention that $\mathrm{N}$ fertilised plots from Riggs et al. (2015) comprised actually: $+\mathrm{N},+\mathrm{NP},+\mathrm{NK}$, $+\mathrm{NPK}$ blocks, while the control (ambient N): + P, + K, +PK blocks. These results are in line with our findings, with cellulose decomposing faster in fallows, characterised by higher $\mathrm{N}$, $\mathrm{P}$, and $\mathrm{K}$ availability, than in meadows and confirms presumption that, at least, easily available $\mathrm{C}$ can be cycled faster in fallows. The slightly slower $\mathrm{C}$ turnover under $\mathrm{N}$ fertilisation in agricultural, ploughed systems and no-change in nonagricultural $\mathrm{N}$ amended soils suggested by Lu et al. (2011) is debatable since the authors did not describe the range of $\mathrm{N}$ doses taken into their meta-analysis and it is not known if there are interactions between them. "The dose alone makes the poison", and $\mathrm{N}$ fertilisation at high amounts can negatively affect decomposition (e.g., Knorr et al. 2005; Zak et al. 2008).

The higher variability of estimated lag-time in meadows than in fallows can be connected with wider range of soil properties and management history in the studied meadows than in young ex-arable fields followed by higher variability of soil microbial structure within the studied meadows (Chmolowska et al. 2016). The particularly low decomposition in meadow 3 may be linked to its higher content of OM, total $\mathrm{C}$ and $\mathrm{N}$ followed by higher WHC and CEC in comparison to other plots, which suggest more humus accumulated. Meadow 3 had the highest plant diversity and richness (Chmolowska et al. 2016). It is possible that meadow 3 was the oldest ecosystem in the study with slower $\mathrm{C}$ and $\mathrm{N}$ mineralisation rates and/or decomposition was retarded by some habitat properties. Even though the low mineralisation activity of the soil microbial communities in meadow 3 , its PLFA and NLFA biomass and phosphatases and urease activity were similar to other fallows and meadows (Chmolowska et al. 2016). The longer start-up in fallow 5 was quickly compensated by the high decomposition rate, so that at the end of incubation, there was no difference in quantity of cellulose decomposed in comparison to other fallows. Fallow 5 contained the lowest soil $\mathrm{OM}$ and total $\mathrm{N}$ contents. It seems that while significant differences in available $\mathrm{N}$ and $\mathrm{P}$ play main roles, differences in $\mathrm{OM}$ content and its composition and availability also play a role in shaping microbial activity and nutrient cycling.

As noticed by Cornwell and Weedon (2014), there are many empirical observations for which the classic exponential decay model does not fit the data satisfactorily. The most commonly used kinetic models of organic matter decomposition do not take into account the time needed by the microbial community to start processing the litter. When measurements are not taken frequently enough from the very beginning of decomposition, or the decomposition is generally slow, this step can be easily overlooked. The decay of cellulose, as studied by Tesařová et al. (1984; in Úlehlová and Tesařová 1988) in a grassland soil under natural conditions and different climatic situations, appeared to comprise three phases. The first phase, characterised by a low $k$, lasted for about 14 days and referred to the microbial community build-up for using a pure $\mathrm{C}$ source. The inductive-like mode of action of cellulases corroborates the observations by Tesařová et al. (1984; in Úlehlová and Tesařová 1988) and our own data. During the second phase, a significant increase in the cellulose decomposition rate took place, followed by a gradual decrease in the decomposition rate in the third phase. Herein, we fitted the
Table 3 Results of fitting the function $\mathrm{ML}=1 /((1 / a)+s$ $\cdot \exp .(-k \cdot \mathrm{t}))($ Eq. 1$)$ and $\mathrm{ML}=\mathrm{a}(1-$ exp.(-k t/a) (Eq. (2)) to Pinus sylvestris L. litter bag decomposition data (Krawczyk 2005); $a$-asymptote, $s$-lag time, $k$ - decomposition rate in exponential phase, $95 \%$ Conf. Int. $-95 \%$ lower and upper confidence intervals

\begin{tabular}{|c|c|c|c|c|c|c|c|}
\hline \multicolumn{4}{|c|}{ Litter from the nitrogen plant Tarnów } & \multicolumn{4}{|c|}{ Control litter Przechód } \\
\hline \multirow[t]{2}{*}{ Parameter } & \multirow[t]{2}{*}{ Estimate } & \multicolumn{2}{|c|}{$95 \%$ Conf. Int. } & \multirow[t]{2}{*}{ Parameter } & \multirow[t]{2}{*}{ Estimate } & \multicolumn{2}{|c|}{$95 \%$ Conf. Int. } \\
\hline & & Lower & Upper & & & Lower & Upper \\
\hline \multicolumn{8}{|l|}{ Eq. 1} \\
\hline$a$ & 66.14 & 64.23 & 68.05 & $a$ & 59.28 & 57.19 & 61.37 \\
\hline$s$ & 0.54 & 0.2 & 0.88 & $s$ & 0.31 & 0.11 & 0.5 \\
\hline$k$ & 2.19 & 1.81 & 2.57 & $k$ & 1.75 & 1.37 & 2.14 \\
\hline \multicolumn{8}{|l|}{ Eq. 2} \\
\hline$a$ & 68.57 & 65.85 & 71.29 & $a$ & 61.85 & 59.41 & 64.29 \\
\hline$k$ & 0.41 & 0.36 & 0.47 & $k$ & 0.39 & 0.33 & 0.44 \\
\hline
\end{tabular}


exponential function with lag-time which mathematically best represented the dynamics of the cellulose decomposition.

The function proposed in our study allows also for estimating an asymptote lower than $100 \%$ decomposition. Because of the constraints of the experimental layout and the substrate used, this was not implemented here (the asymptote was set to $100 \%$ in all cases) but the option may be useful in studies on decomposition of more complex substrates, e.g., natural litter. We tested this by fitting the lag-time asymptotic model (Eq. (1)) and the asymptotic model without lag-time: $\mathrm{ML}=\mathrm{a}\left(1-\mathrm{e}^{-\mathrm{kt} / \mathrm{a}}\right)($ Eq. 2) (Berg and Laskowski 2006) to the data from a Pinus sylvestris L. litter bag study by Krawczyk (2005). In that study, litter decay was compared between an area heavily contaminated with nitrogen, near a nitrogen plant station in Tarnów, south Poland, and a clean site. The Scots pine litters were incubated in 1-mm mesh polyethylene bags and were sampled after 1, 2, 6, 12, and 18 months (Krawczyk 2005). For the nitrogen-polluted litter, the lag-time asymptotic model showed a slightly better fit than Eq. (2), with $R^{2}=94.3$ against $91.6 \%$. For the control plot both functions fitted the data equally well $\left(R^{2}=91.2 \%\right.$ for the lag-time model, and $91.6 \%$ for Eq. (2)). Both functions pointed to more decomposed pine litter in N-polluted area than in control plot, although the lag-time asymptotic model (Eq. (1)) returned slightly narrower confidence intervals of asymptotes than the model without lag time (Eq. (2)). Asymptotes estimated with the lag-time asymptotic model were lower by about $2-3 \%$ but the difference cannot be considered significant as the confidence intervals for the parameter $a$ overlapped between the models. However, in both litters the lag-time (shape parameter $s$ ) was significant, what affected also the decomposition rate constant $k$, which was significantly higher in the lag-time asymptotic model (Table 3). There was no difference in lagtimes $(s)$ or decomposition rate constants $(k)$ between $\mathrm{N}$ polluted and control litters. Significant parameter $s$ suggests the applicability of the lag-time asymptotic model in studies on litter decomposition. Indeed, as demonstrated by Cornwell and Weedon (2014), incorporating initial lag-time in the model provides more flexibility for representing the wide array of possible decomposition dynamics encountered in nature.

In general terms, the lag-time asymptotic model allows for a deeper insight into the decomposition process than the commonly used simple exponential or asymptotic functions do. The model fit well all tested data, including the laboratory cellulose decomposition and the typical litter-bag study. Incorporating a lag-time in the model indicated that the major difference in cellulose decomposition between the fallows and the meadows was the postponed start of decomposition in the meadows, while the decomposition rate constants were similar at the exponential phase in both ecosystem types. Fitting the function requires, however, more frequent sampling at the beginning of the decomposition so that the lag-time phase is adequately captured. If there are good premises that the decomposition asymptote may be lower than $100 \%$, the decomposition also has to be followed long enough to cover the period when the decay starts to slow down.

Acknowledgments This research was performed at the Jagiellonian University in Kraków, Poland (grant No. DS 759). The first author's $\mathrm{PhD}$ thesis included material from this work. We thank Karolina Kozupa for her laboratory assistance, in particular for the replication of cellulose strips examination. We also thank Magdalena Krawczyk for letting us use her data on litter decomposition.

Open Access This article is distributed under the terms of the Creative Commons Attribution 4.0 International License (http:// creativecommons.org/licenses/by/4.0/), which permits unrestricted use, distribution, and reproduction in any medium, provided you give appropriate credit to the original author(s) and the source, provide a link to the Creative Commons license, and indicate if changes were made.

\section{References}

Bayer E, Shoham Y, Lamed R (2006) Cellulose-decomposing bacteria and their enzyme systems. The prokaryotes 2:578-617

Berg B, Laskowski R (2006) Changes in substrate composition and rateregulating factors during decomposition. Adv Ecol Res 38(4):123

Berg B, McClaugherty C (2008) Plant Litter. Decomposition, humus formation, carbon sequestration. Springer-Verlag, Berlin, Heidelberg

Burel F, Baudry J (1995) Species biodiversity in changing agricultural landscapes: a case study in the pays d'Auge, France. Agric Ecosyst Environ 55:193-200

Chapman SK, Langley JA, Hart SC, Koch GW (2006) Plants actively control nitrogen cycling: uncorking the microbial bottleneck. New Phytol 169 (1):27-34

Chen H (2014) Biotechnology of lignocellulose: theory and practice. Springer, Chemical Industry Press, Dordrecht, Heidelberg, New York, London

Chmolowska D, Kozak M, Laskowski R (2016) Soil physicochemical properties and floristic composition of two ecosystems differing in plant diversity: fallows and meadows. Plant Soil 402:317-329

Cornwell WK, Weedon JT (2014) Decomposition trajectories of diverse litter types: a model selection analysis. Methods Ecol Evol 5(2): $173-182$

Garnier E, Cortez J, Billès G, Navas ML, Roumet C, Debussche M, et al. (2004) Plant functional markers capture ecosystem properties during secondary succession. Ecology 85(9):2630-2637

Göransson H, Venterink HO, Bååth E (2011) Soil bacterial growth and nutrient limitation along a chronosequence from a glacier forefield. Soil Biol Biochem 43(6): 1333-1340

Grunda B (1967) Metoda hodnocení rozkladu celulózy v lesních půdach. Lesnický časopis 9:807-813

Hobbie SE, Vitousek PM (2000) Nutrient limitation of decomposition in Hawaiian forests. Ecology 81(7):1867-1877

Kamble PN, Bååth E (2014) Induced N-limitation of bacterial growth in soil: effect of carbon loading and $\mathrm{N}$ status in soil. Soil Biol Biochem 74:11-20

Keenleyside C, Tucker G (2010) Farmland abandonment in the EU: an assessment of trends and prospects. London: WWF and IEEP (November) 93 
Kirkby CA, Richardson AE, Wade LJ, Batten GD, Blanchard C, Kirkegaard JA (2013) Carbon-nutrient stoichiometry to increase soil carbon sequestration. Soil Biol Biochem 60:77-86

Kirkby CA, Richardson AE, Wade LJ, Batten GD, Blanchard C, Kirkegaard JA (2014) Nutrient availability limits carbon sequestration in arable soils. Soil Biol Biochem 68:402-409

Knorr M, Frey SD,Curtis PS (2005) Nitrogen additions and litter decomposition: A meta-analysis. Ecology 86 (12):3252-3257

Krawczyk M (2005) Tempo dekompozycji igieł sosny zwyczajnej (Pinus sylvestris L.) warunkowane zanieczyszczeniami przemysłowymi. Doctoral dissertation. University of Silesia in Katowice, Biology and Environmental Protection Faculty

Laskowski R (2012) What determines forest litter decomposition? Global trends and local variance. Geogr Polon 85(2):39-46

Losvik M (1999) Plant species diversity in an old, traditionally managed hay meadow compared to abandoned hay meadows in Southwest Norway. Nordic J Bot 19:473-487

Lu M, Zhou X, Luo Y,Yang Y, Fang C, Chen J, Li B (2011) Minor stimulation of soil carbon storage by nitrogen addition: A metaanalysis. Agric Ecosyst Environ 140(1-2):234-244

Lynd LR, Weimer PJ, van Zyl WH, Pretorius IS (2002) Microbial cellulose utilization: fundamentals and biotechnology. Microbiol Mol Biol Rev 66(3):506-577

Mitlacher K, Poschlod P, Rosén E, Bakker JP (2002) Restoration of wooded meadows - a comparative analysis along a chronosequence on Öland (Sweden). Appl Veg Sci 5:63-73

Olson JS (1963) Energy storage and the balance of producers and decomposers in ecological systems. Ecology 44:322-331
Pavlů V, Hejcman M, Pavlů L, Gaisler J, Nežerková P, Guerovich Andaluz M (2005) Vegetation changes after cessation of grazing management in the Jizerské Mountains (Czech Republic). Ann Bot Fenn 42:343-349

Renwick A, Jansson T, Verburg PH, Revoredo-Giha C, Britz W, Gocht A, McCracken D (2013) Policy reform and agricultural land abandonment in the EU. Land Use Policy 30(1):446-457

Riggs CE,Hobbie SE,Bach EM, Hofmockel KS, Kazanski CE (2015) Nitrogen addition changes grassland soil organic matter decomposition. Biogeochemistry 125(2):203-219

Tasser E, Tappeiner U (2002) Impact of land use change on mountain vegetation. Appl Veg Sci 5:173-184

Toky O, Ramakrishnan P (1984) Litter decomposition related to secondary succession and species type under slash and burn agriculture (Jhum) in north-eastern India. Proc Indian Natn Sci Acad 1:57-65

Úlehlová BA, Tesarová M (1988) Cycling of mineral elements. In: Vancura V, Kunc F (eds) Soil microbial associations: control of structures and functions. Developments in Agricultural and Managed Forest Ecology 17, Elsevier, p 370

White R, Muray S, Rohweder M (2000) Pilot analysis of global ecosystems: grassland ecosystems technical report. World Resources Institute, Washington, DC

Wilson DB (2011) Microbial diversity of cellulose hydrolysis. Curr Opin Microbiol 14(3):259-263

Wolfenden R, Snider MJ (2001) The depth of chemical time and the power of enzymes as catalysts. Acc Chem Res 34(12):938-945

Zak DR, Holmes WE, Burton AJ, Pregitzer KS, Talhelm AF (2008) Simulated atmospheric no deposition increases soil organic matter by slowing decomposition. Ecol Appl 18(8):2016-2027 